\title{
Influence of Earnings per Share on Idiosyncratic Volatility of Stock Returns among Listed Firms in Kenya
}

\author{
${ }^{*}$ Job Cheruiyot Aiyabei Dr. Olweny Tobias Dr. Irungu Macharia \\ School of Human Resource Development, Jomo Kenyatta University of Agriculture and Technology, \\ P.O BOX 00200-62000, Nairobi, Kenya
}

\begin{abstract}
Idiosyncratic volatility has not always been considered in pricing of financial assets; this is as a result of capital asset pricing model's proposition that idiosyncratic volatility is diversifies away and that investors hold portions of diversified portfolio. In reality however, this is not always the case. Research studies have revealed that investors do not always hold diversified portfolios and idiosyncratic risk is therefore priced in order to compensate their inability to hold the market portfolio, therefore the main objective of the study was to establish the effect of financial statement information on idiosyncratic volatility of stocks return among listed firms in Kenya. Idiosyncratic volatility was the dependent variable while independent variable was Earning Per Share (EPS). The study used correlational and descriptive research design, it also used census technique which targeted all 39 listed companies that existed and their shares were actively traded at the Nairobi Securities Exchange (NSE) from the year 1998 to 2017. STATA was used to generate Descriptive and inferential statistics. The study employed a dynamic panel data regression model, the analysis of variance (ANOVA) was used to reveal the overall model significance, the calculated F-statistic was compared with the tabulated F-statistic and a critical pvalue of 0.05 was used to determine whether the overall model is significant. The study results found that there was a positive and significant relationship between EPS and Idiosyncratic Volatility of stock returns among listed firms in Kenya $(\mathrm{r}=0.001, \mathrm{p}=0.027)$, and therefore the null hypotheses were rejected. Based on the findings, the study concluded that, EPS has a significant relationship with Idiosyncratic Volatility of stock returns among listed firms in Kenya. The study recommended that market investors analyst should review their investment strategies taking into consideration EPS in pricing firm specific risk. These indicators will further guide in expanding the interpretation of the financial dynamics in the listed firms at the NSE and other related firms.
\end{abstract}

Keywords: Earnings per Share, Idiosyncratic Volatility, Stock Returns, NSE \& Kenya.

DOI: $10.7176 /$ RJFA/10-22-03

Publication date: November $30^{\text {th }} 2019$

\subsection{Introduction}

The value relevance of financial statement has grown significantly over the last two decades, this can be attributed to general acceptance and harmonization of accounting standards as well as global adoption of international financial reporting standard (IFRS) and international accounting standards (IAS). Value relevance is based on the pillars of reliability and relevance as well as the ability of financial information to summarize stock market data, it also describes the relationship between accounting information and equity prices (Liu \& Liu, 2007). Basically, listed companies use published financial statements as a major away for communicating financial information to their shareholders and all stakeholders (Nassar, Uwuigbe, Uwuigbe \& Abuwa, 2014). Studies have also shown that there is correlation between financial accounting information and equity price volatility in the securities market Zhou (2004), Sharma (2011), Halonen, Pavlovic and Persson (2013).

The use of published financial statements in investment decision at the stock exchange and its impact of equity price volatility has not been widely studies in Africa, studies done elsewhere have resulted in mixed findings. Halonen and Pavlovic (2013) analyzed the effect of EPS, EPS and BVPS on stock price of firms listed at Swedish equities market, their findings showed that equity price volatility is significantly affected by financial statement information. According to Spiegel and Wang (2005) idiosyncratic volatility and liquidity have an inversely relationship and conclude that the correlation between idiosyncratic volatility and market returns could also indicate both the relationship between liquidity and returns and the correlation between firm size and returns.

According to Wang and Chang (2008), there exist a significant and positive association linking stock price and book value and also between equity price and EPS at the Taiwanese stock exchange. De, Medeiros \& Lago (2014) investigated the relationship between financial accounting information and volatility of share returns in listed Brazilian firms, the empirical findings showed that the level of financial accounting information disclosure has a significant and negative effect on securities market risk measured by stock return volatility. Almeri, AlFarah, and Shanikat (2014) study did not find significant correlation between accounting information variables and stock volatility with the financial accounting information only explaining $2.6 \%$ of the volatility experienced in the stock prices. In his study, Abo Osba (2007) study found strong and highly significant correlation between share prices movement in the banking sector and cash dividend payout and the Amman Stock Exchange.

Studies has also found that, for some reasons, investors always do not hold diversified portfolio which 
usually eliminate significantly idiosyncratic volatility as supported by CAPM (Fazil, 2013). Goetzman and Kumar (2008) found that $25 \%$ of investors hold only one stock, and $50 \%$ of investor portfolios contained less than 3 stocks while less that $10 \%$ of their portfolios contain less than 10 stocks. Other studies document that investors do not react to published accounting information even when it leads sharp movement in stock prices (Bushee \& Noe (2000); Gleason \& Lee (2003). Therefore, investors who are not able to diversify their portfolios should consider idiosyncratic risk beside systematic risk in projecting expected market return. This paper therefore seeks to establish the effects of EPS on idiosyncratic volatility of stock returns among listed firms in Kenya.

\subsection{Problem Statement}

Idiosyncratic volatility has always been ignored in asset pricing; this is due to capital asset pricing model's (CAPM) suggestion that idiosyncratic volatility is diversified away since investors hold a proportion of the well diversified market portfolio (Sandberg, 2005). In reality however, this is not always the case. Studies has also found that, for some reasons, investors always do not hold diversified portfolio which usually eliminate significantly idiosyncratic volatility as supported by CAPM (Fazil, 2013), and idiosyncratic risk is priced to compensate investors for their inability to hold the market portfolio (Fu, 2009; Eiling, 2008; Malkiel and Xu, 2006; Fazil, 2013; Boloorforoosh, 2014). With increasing number of empirical studies indicating that financial accounting information affect stock prices volatility (Yu and Huang, 2005; Sharma, 2011; Glezakos, 2012; Sibel, 2013), and with the growth of NSE over the decade, more specificly the growth of active investors, equity turnover and market capitalization; which has led to increased stock price movement and market volatility (Kihara, 2011), there is need to investigate the effect of published financial statement information on idiosyncratic volatility equities price listed at the NSE.

Studied conducted elsewhere have yielded mixed finding, Halonen, Pavlovic and Persson (2013) found that accounting data explains a high portion of stock price movement in Swedish stock market. Abo-Osba (2007) study results showed a statistically significant strong positive correlation between published financial accounting variables and equity prices volatility, Wang and Chang (2008) also noted that there was a positively significant relationship between book value and stock price as well as between EPS and equity price at the Taiwan securities exchange. On the other hand, Hussainey (2011) found a significant and negative relationship between the payout ratio, dividend yield and the firm volatility of stock price at the London equities market. Xing and Zhang (2008) found that there is a negative relationship between EPS and idiosyncratic volatility in the G7 countries. Razaq and Almeri (2014) considered the potential of published accounting data to explain volatility of stock prices at the Amman stock market, the study concluded that the accounting variables explained only $3.8 \%$ of the volatility in stock price while $96.2 \%$ of the volatility in stock price referred to other reasons. Al-Farah, Almeri and Shanikat (2014) study indicated lack of significant correlation between accounting variables and the volatility with the accounting data explaining only $2.6 \%$ of the volatility in the listed equity prices.

These mixed and contradictory results of studies done across different exchanges globally form the research gap and basis of undertaking this study. Therefore, this study sought to establish the effect of EPS on idiosyncratic volatility of stocks return listed at the NSE

\subsection{Objective of the Study}

To establish the effect of EPS on idiosyncratic volatility of stock returns among listed firms in Kenya.

\subsection{Research Hypothesis}

$\mathbf{H}_{\mathbf{0}}$ : EPS has no significant effect on idiosyncratic volatility of stock returns among listed firms in Kenya.

\subsection{Scope of the Study}

The study looks at financial statement information which is EPS from firms listed in Nairobi Securities Exchange (NSE). This study took into consideration only the companies that existed and their shares were actively traded at the NSE from the year 1998 to the year 2017. Following the criterion employed by Fu (2009), the researcher zeroed in on the stocks that were traded for a minimum of 15 days during each month of the sample period.

\subsection{Literature Review}

\subsubsection{Theoretical Literature: Signaling Theory}

The signaling concept was first studied by Akerlof and Arrow in the context of commodities markets and employment, it was letter advanced by Spence (1973) into signal equilibrium theory, which says, by conveying a credible signal on its quality to the financial markets, a good firm is able to bring out a difference between itself and a bad firm. Ross (1977) indicated how debt obligations could be utilized as a costly signal to bring a difference between a good firm from a bad one. Under the asymmetric information linking investors and 
management, company's signals are important in bringing out financial resources. Ross proposed that, as opposed investors, managers have a clear knowledge of the actual distribution of company returns.

Heinkel (1982), Kraus and Rennan (1984) proposed the costless signaling equilibrium, which states that a signal is costly if the development of the same take up resource or if it is association with welfare loss produced by the departure from distribution of claims in perfect markets. Poitevin (1989) indicated that a firm can use debt as a signal to show the difference between itself and new competition.

According to signaling theory, announcements by listed corporations are hypothesized to contain useful information, for instance, cash dividend announcement is used by management to signal the change in companies future prospect expectation when the markets are not perfect. The financial and companies' investment decisions are made by managers at their own discretion. An increase in shares floated by a listed firm leads to reduction in its share price, shock split courses an increase in equity price, while increase in debt result in price increase actions. However, although dividend declaration is used by management to convey information, the change in dividend my not necessarily be a perfect signal conveyer. According to Easterbrook (1994), increase in dividend payout could be an ambiguous signal unless the participants in the financial market can differentiate between a company that is growing and the one that is disinvesting.

Modigliani and Miller (1961) also proposed that dividend have a signaling effect. The management of a company are more informed regarding the company's performance strategy and can easily forecast its future earnings. Therefore, company employees are more informed that the general market and other investors, this therefore leads to information asymmetry problem. For that reason, dividend can be used by firms a signaling tool to send information to its shareholders and the market as a whole, this information may reflect new approach that the company will adopt in the short, medium and long term. The expectation of investors about the future earning of the company can be changed by the managers, A company has many ways of sending signals to the market. This may include costly strategies that deter smaller companies from emulating the signal, their strategy may include increasing dividend payout.

Signaling theory has progressively become appealing to strategic management research (Bergh and Gibbons, 2011). This is primarily because according (Bergh, 2014), to the theory focusses strongly on the difficulties facing strategic decision makers, this includes how the signal can be employed in reducing uncertainties with exists during a selection process in a situation with incomplete and asymmetrically distributed information.

\subsection{Conceptual Framework}

The independent variable in this study is Earnings per share, which affect the dependent, Idiosyncratic volatility of listed stocks as shown in Figure 1.

\begin{tabular}{|l|l|}
\hline $\begin{array}{l}\text { Earnings per Share } \\
\text {-Profit after tax/No. of ordinary } \\
\text { shares }\end{array}$ & $\begin{array}{l}\text { Idiosyncratic Volatility } \\
\text { Standard deviation of the residual } \\
\left(\varepsilon_{i t}\right) \text { from single index model }\end{array}$ \\
\cline { 2 - 3 } & \\
\hline Independent Variable & Dependent Variable \\
\hline
\end{tabular}

Figure 1: Conceptual Framework

\subsection{Empirical Review}

\subsubsection{Earnings and Idiosyncratic Volatility}

Company earnings is one of the important information component utilized by investors in making critical investment decisions, it forms a basis of stake holders decision on whether to invest or divest in a targeted firm, the impact of earnings on equity risk has been investigated from many point of view and various strategies adopted to find out its influence on stock price movement. (Ghosh and Ghosh, 2015) conducted a study on whether corporate accounting disclosures through annual report influence stock price volatility in Dhaka Stock Exchange. The study utilized panel data from 25 privately owned commercial banks for a four-year period starting in 2010 to 2014. The results revealed that book value, return on equity and EPS influenced positively stock price volatility while asset per share and EPS explained jointly highest variation in equity price volatility Mgbame and Ikhatua (2013) found that earnings per share significantly influence stock price volatility at the Nagerian stock market

Wang and Luo (2013) looked at the correlation between accounting data and share price movement in Shanghai securities market, using 60 companies listed at the exchange between 2011 and 2013. The findings indicated existence of a positive relationship linking accounting information and share price, however, return on equity and EPS were the most significantly correlated. After studying the impact of accounting information on 
the volatility of stock price Halonen,Pavlovic and Persson (2013) established that a high percentage of stock price movement in the Swedish stock market is as a result of EPS. Piotroski and Roulstone (2004) on the other hand came to a conclusion that market prices depends on supply and demand of the specific holding in the market and certainly not as a result of the profitability of a specific asset.

After examining the impact of EPS on stock prices of the banking sector listed in Amman stock exchange over the years 2001-2005, Abo Osba (2007) found existence of relationship linking equity prices movement and earnings. Almeri, Al-Farah, and Shanikat (2014) on the other hand found no correlation between accounting data and share price volatility. Pastor and Veronesi (2003) indicated that significant uncertainty about a firm's average profitability influences stock return movement, To the extent that financial reporting quality is poor, uncertainty about a firm's future profitability is likely to be high.

Dongwei (2003) analyzed stock price reactions to earnings announcements in the Chinese market, He sampled 183 earnings announcements between 1996 and 1998, using an event study methodology, and he found that the stock price reactions to change in earning per share in the Chinese stock markets. He also found that domestic investors do not correctly anticipate the changes in earnings and fail to adjust new earnings information quickly, but international investors can predict earnings changes better than domestic investors can. As a result, abnormal returns can be obtained by trading on the earnings information for domestic investors only. He explained that most domestic investors are individuals with short-term investment horizon while most foreign investors are large institutions that trade on more detailed and accurate financial information not immediately available to domestic investors.

\subsection{Methodology}

This study employed correlational and descriptive research design because it is based on the premise that if a statistically significant relationship exists between two variables, then it is possible to predict one variable using the information available on another variable. Target and accessible population for this study comprised of the 39 listed companies that existed and their shares were actively traded at the NSE from 1998 to 2017. In this study, the researcher used census study, a census study is any inquiry of the entire population of a particular set of 'objects', it is a complete enumeration of all items in the population. The researcher collected annual published financial statements for all 39 sampled listed companies for the twenty-year period under study (1998 to 2017). The financial statements were obtained from specific listed company's websites and NSE handbook. A research assistant was engaged to extract the required accounting data (EPS) for all companies in all the financial years under review. The extracted data was input to pre-structured work sheet and then converted into STATA format.

The secondary data encompassed panel data which consists of time series and cross-sections. The panel data obtained was analyzed using descriptive statistics, correlation analysis, and panel regression analysis.

Autocorrelation, heteroscedasticity, and panel unit root tests were conducted to ensure proper specification. The panel methodology was supported by STATA software. Feasible Generalized Least Square estimation was performed after accounting for various violations of classical linear assumptions. The analysis of variance (ANOVA) was checked to reveal the overall model significance.

To estimate idiosyncratic volatility for sampled stocks at the NSE, the researcher employed the standard deviation of the regression residual $\left(\varepsilon_{i t}\right)$ from Single Index Model as outlined in Malkiel and Xu (2003).

$\mathrm{R}_{i, t}-\mathrm{R}_{\mathrm{f}, \mathrm{t}}=\alpha_{\mathrm{i}}+\beta_{\mathrm{i}}\left(\mathrm{R}_{m, t}-\mathrm{R}_{f, t}\right)+\varepsilon_{i, t}$

Where: $i=$ Specific stock,

$\mathrm{R}_{\mathrm{m}}=$ Return on the all ordinaries index

$\mathrm{t}=$ Time interval

$\mathrm{R}_{i, t}-\mathrm{R}_{\mathrm{f}, \mathrm{t}}=$ Excess return of firm $i$ in month $\mathrm{t}$

$\mathrm{R}_{m, t}-\mathrm{R}_{f, t}=$ Excess market return in month $\mathrm{t}$

$\varepsilon_{\text {it }}=$ regression residual.

The specific model used in the study is defined as follows:

Yit $=\beta_{0}+\beta$ Xit + eit

Where

$\mathrm{Y}$ it $=$ Idiosyncratic volatility of firm $i$ at time $t$;

$\mathrm{Xit}=\mathrm{EPS}$ of firm $\mathrm{i}$ at time $t$;

$\beta_{0}=$ the constant term

$\beta_{\mathrm{s}}=$ The coefficients for the independent variable

Subscript $i=$ Firms (cross-section dimensions) ranging from 1 to 39;

Subscript $t=$ Years (time-series dimensions) ranging from 1998 to 2017;

cit $=$ error term of the model. 


\subsection{Results and Findings}

Table 1 shows the mean, minimum, and maximum values with standard deviation of various variables used in the model for period 1998-2017.

Table 1: Descriptive Statistics

\begin{tabular}{lccccc}
\hline Variables & Obs & Minimum & Mean & Maximum & Std. Deviation \\
\hline EPS & 780 & 0.005 & 6.645 & 63.406 & 9.515 \\
Idiosyncratic Volatility & 780 & 2.044 & 26.000 & 28.890 & 4.251 \\
\hline
\end{tabular}

Table 1 shows all the variables share the same sample size of 780 observations. The results showed that the mean of EPS was 6.645 with a minimum of 0.005 and a maximum of 63.406 . The standard deviation of EPS was 9.515 indicating variability in EPS over time.

\subsection{Correlation Analysis}

The study conducted correlation analysis for the EPS on Idiosyncratic Volatility in order to examine the nature of the statistical relationships between the variables. Table 2 shows the correlation matrix the variables included in the study.

Table 2: Correlation Matrix Results

\begin{tabular}{lcc}
\hline Variables & Idiosyncratic Volatility & BVPS \\
\hline Idiosyncratic Volatility & 1.000 & \\
EPS & $0.3950^{* *}$ & BVPS \\
\end{tabular}

The results showed that EPS $(0.395,0.000)$ had a positive and significance relationship with Idiosyncratic Volatility of stock returns among listed firms in Kenya.

\subsection{Diagnostics Test}

\subsubsection{Panel Unit Root Tests}

Unit root tests was conducted using the LLC test to establish whether the variables were stationary or nonstationary. The purpose of this is to avoid spurious regression results being obtained by using non-stationary series. Results in Table 3 indicated that the variables are stationary (i.e. absence of unit roots) at 5\% level of significance.

Table 3: Unit root

\begin{tabular}{lccc}
\hline Variable name & Statistic(adjusted) & P-value & Comment \\
\hline Idiosyncratic Volatility & 6.0376 & 0.010 & Stationary \\
EPS & 7.5091 & 0.000 & Stationary \\
\hline
\end{tabular}

The study therefore concludes that the two variables under consideration do not have unit root and are therefore used in levels. This means that the results obtained are not spurious (Gujarati, 2003

\subsubsection{Heteroskedasticity Test}

Heteroscedasticity test was performed so as to determine if the error term is correlated across observation in the time series data. The error terms from a regression model must have a constant variance called Homoscedastic and to ensure whether the residuals meet this criterion of the study used the Breusch-Pagan test for Heteroscedasticity where the null hypothesis under this test is that residuals are Homoscedastic. If the p-value is $>0.05$, there is constant variance. The null hypothesis was therefore not rejected at a critical $\mathrm{p}$ value of 0.05 since the reported value was 0.887 . Thus, the data did not suffer from statistically significant heteroscedasticity as shown in Table 4

\section{Table 4: Heteroskedasticity Test Results}

\section{Breusch-Pagan / Cook-Weisberg test for heteroscedasticity}

Ho: Constant variance

Variable: fitted values

Idiosyncratic Volatility

$\begin{array}{llc}\text { chi2 }(39) & = & 59528.65 \\ \text { Prob }>\text { chi2 } & = & 0.887\end{array}$

\subsubsection{Test for autocorrelation}

The study used Wooldridge test in order to detect the existence of autocorrelation in the data, the test assisted the researcher to know whether or not the residual is serially correlated over time and the results are shown in Table 5. The null hypothesis of this test was that there is no first order serial/autocorrelation existed in the data. The test statistic reported is F-test with one and 38 degrees of freedom and a value of 438.94. The P-value of the Ftest is 0.260 indicating that the F-test is not statistically significant at $5 \%$ level. Hence, the null hypothesis of no autocorrelation is supported and the study concludes that residuals are not auto correlated. 
Table 5: Serial Correlation Tests

Wooldridge test for autocorrelation in panel data

H0: no first-order autocorrelation

$\mathrm{F}(1,38)=438.94$

Prob $>\mathrm{F}=0.260$

\subsubsection{Hausman Test}

When performing data analysis, it is important to ascertain whether to perform a random effects model or a fixed effects model (Baltagi, 2005). This will assist in making decision on the most suitable model to use, both random and fixed effects estimate coefficients. The researcher used Hausman's specification test (1978) to select between fixed and random effect models. Table 6 shows the results of Hausman test

Table 5: Hausman Test for Idiosyncratic Volatility

\begin{tabular}{lcccc}
\hline & $\begin{array}{c}(\mathbf{b}) \\
\text { fixed }\end{array}$ & $\begin{array}{c}\text { (B) } \\
\text { Random }\end{array}$ & $\begin{array}{c}\text { (b-B) } \\
\text { Difference }\end{array}$ & Sqrt (diag(V_b-V_B)) \\
\hline EPS & 0.00205 & 0.00222 & -0.00018 & 0.00029 \\
chi2(4) & 0.73 & & & \\
Prob $>$ chi2 & 0.941 & & & \\
\hline
\end{tabular}

The null hypothesis of the Hausman test is that the random effects model is preferred to the fixed effects model. Hausman test reveals a chi-square of 0.73 with a p-value of 0.941 indicating that at 5 percent level, the chi-square value obtained is statistically insignificant. Thus, the researcher did not reject the null hypothesis that random effects model is preferred to fixed effect model for Idiosyncratic Volatility. Therefore, random effects model for Idiosyncratic Volatility was therefore adopted.

\subsection{Regression Analysis}

\subsubsection{Effect of EPS on Idiosyncratic Volatility}

Regression analysis was conducted to determine whether there was a significant relationship between. As presented in the Table 4.8, R Square is 0.3133 . The model shows that EPS explains $31.33 \%$ of the variation in Idiosyncratic Volatility. This means $31.33 \%$ of the Idiosyncratic Volatility is influenced by EPS.

Table 4.8: Earnings per Share on Idiosyncratic Volatility

\begin{tabular}{lcccccc}
\hline Idiosyncratic Volatility & Coef. & Std. Err. & T & P> $>|\mathbf{t}|$ & $\mathbf{9 5 \%}$ Conf. & Interval \\
\hline EPS & 0.001 & 0.001 & 2.210 & 0.027 & 0.000 & 0.003 \\
Cons & 25.948 & 0.027 & 944.64 & 0.000 & 25.894 & 26.002 \\
R-sq: & 0.3133 & & & & & \\
F(1,779) & 4.89 & & & & & \\
Prob & 0.027 & & & & & \\
\hline
\end{tabular}

The fitted model from the result is

$\mathrm{Y}=25.948+0.001 \mathrm{X}$

Where: $\mathrm{Y}=$ Idiosyncratic Volatility

$$
\mathrm{X}=\mathrm{EPS}
$$

The findings further confirm that the regression model of Idiosyncratic Volatility on EPS index is positive and significant with a coefficient of $(r=0.001, p=0.027)$ supported by $F=4.89$. This is also confirmed by the $t-$ statistic value of 2.210 which was greater than the t-critical of 1.96 . This shows resistance of positive and significant relationship between EPS and Idiosyncratic Volatility since the coefficient value was positive and the p-values was 0.027 that is less than 0.05 . This means that a unitary increase in EPS increases Idiosyncratic Volatility by 0.001 units holding other factors constant.

This is consistent with Wang and Chang (2008) who found a positively significant relationship between EPS and stock price movement at the TSE. Shehzad and Ismail (2014) accounting information explains a high percentage of stock price movement while EPS is more value relevant as compared with book values.

\subsection{Hypotheses Testing}

The hypothesis to be tested was:

$H_{0}$ : EPS has no significant effect on idiosyncratic volatility of stock returns among listed firms in Kenya

The hypothesis was tested by using multiple linear regression and determined using p-value. The acceptance/rejection criteria was that, if the $\mathrm{p}$ value is less than 0.05 , we reject the $\mathrm{H}_{01}$ but if it is more than 0.05 , the $\mathrm{Ho}_{1}$ is not rejected. The results in Table 4.13 indicate that there was a positive and significant relationship between EPS and IV of listed firms in Kenya $(r=0.002, p=0.012)$. This was supported by a calculated t-statistic of 2.903 that is larger than the critical t-statistic of 1.96. The null hypothesis was therefore rejected. The study therefore adopted the alternative hypothesis that EPS has a significant effect on Idiosyncratic Volatility of stock returns among listed firms in Kenya. 


\subsection{Conclusions}

Based on the findings, the study concluded that financial statement information represented by EPS significantly influences Idiosyncratic Volatility of stock returns among listed firms in Kenya, more specifically, from the regression analysis results, EPS has a positive and significant effect on Idiosyncratic Volatility of listed firms in the Nairobi securities exchange. The earning per share is therefore a useful determinant of Idiosyncratic Volatility, and when compared with earning per share of other similar companies, it gives a view of the comparative earning power of the companies.

EPS when calculated over a number of years indicates whether the earning power of the company has improved or deteriorated. Growth in EPS is therefore an important measure of management performance and Idiosyncratic risk because it shows how much money the company is making for it's shareholders, not only due to changes in profit, but also after all the effects of issuance of new shares.The study also concludes that published financial statement information, specifically EPS is key in determining firms' specific risk and should be considered by all investors in their investment decision making.

\subsection{Recommendations}

Security market investors and analyst needs to review their investment strategies and take into consideration EPS in pricing firm specific risk. They need to remain innovative in technology front in order to deliver efficient as well as highly customized asset pricing tools that consider idiosyncratic volatility, this will enable them make a sound investment decision that suit customers investment preference.

Due to the importance of published financial statement information in investment decisions and risk analysis of specific firms at the securities exchange, it is essential that financial information be released to the public and the same be made available in a simplified manner to enable investors including retail investors to make prudent investment decision based on fundamental information.

\subsection{References}

Abken, A. and Nandi, (1996) Options and Volatility, Economic Review- Federal Reserve Bank of Atlanta

Abo-Osba, A. M. (2007), Impact of share and the book value of stock and the cash dividend on the stock's prices in Amman financial market, unpublished thesis, Amman Applied Science Private University

Akerlof, G. (1970) The Market for Lemons: Quality Uncertainty and the Market Mechanism, Quarterly Journal of Economics in 1970.

Al-Farah, Almeri and Shanikat (2014).The Accounting Variables' Ability in Explaining the Volatility of Stock's Price: The Case of Amman Stock Exchange, European Journal of Management.

Ang, A., Hodrick, R. J., Xing, Y., and Zhang, X. (2009). High idiosyncratic volatility and low returns: international and further U.S. evidence. Journal of Financial Economics.

Ashton, D., Peasnell, K. and Wang, P. (2011): Residual Income Valuation Models and Inflation, European Accounting Review, 20:3, 459-483

Ayzer, B.F. \&Cema, I. (2013). Effects of new financial report standards on value relevance. A study of Turkish stock markets. International Journal of Economics and Finance.http://ccsenet.org/journal/index.php/ijef/article/viewFile/30676/18065.

Bailey, R. A (2008).Design of comparative experiments. Cambridge University Press.

Baker, H.K, Veit, E.T., \& Powel, G.E. (2001). Factors influencing dividend policy decisions of NASDAQ firms. The Financial Review.

Bryman, A. and Bell, D. (2007).Quantitative Data Analysis with SPSS for Windows. Routledge, London

Burns, N and Grove, S. K. (2003) Understanding nursing research $3^{\text {rd }}$ Edition. Philadelphia: W. B. Saunders Company.

Bushee, B. and Noe F. (2000): Corporate disclosure practices, institutional investors and

Bushman and Smith, A. (2003). Transparency, Financial Accounting Information, and Corporate Governance. FRBNY Economic Policy Review. University of Chicago Graduate School of Business.

Bushman, R. and Smith, A. (2000). "The Sensitivity of Corporate Governance Systems to the Timeliness of Accounting Earnings." University of Chicago working paper.

Chessar M. (2015) Effect of firms' market capitalization on stock market volatility of companies listed at the NSE. University of Nairobi.

Chinese markets. Review of Financial Economics 12 (2003) 271-286. Department of Finance, Jinan University, Guangzhou, Guangdong 510632, China

Creswell, W. (1994), Research Design: Qualitative and Quantitative Approaches, Sage: Thousand Oaks.

De Medeiros and Lago (2014). Disclosure of Accounting Information and Stock Return Volatility in Brazil. Research Gate. Sao Paulo. Brazil

Deloite Plus (2015). IFRS in your pocket 2015, Deloitte IFRS Publications

Eiling, E. (2008) Can non-tradable assets explain the apparent premium for idiosyncratic risk. The case of 
industry-specific human capital, Working Paper, University of Toronto.

Elliott B and Elliott J (2009). Financial accounting and reporting, Thirteenth edition, Pearson Education Limited. London, United Kingdom.

Fama, E. (1970) Efficient Capital Markets: A Review of Theory and Empirical Work. Journal of Finance, Volume 25.Twenty eight annual meeting of American Finance Association New York.

Fazil (2013). Does Idiosyncratic Volatility Matter in The Emerging Markets? Istanbul Stock Exchange Evidence. Ankara University, Faculty of Political Sciences. Turkey

Fernanda, M. and Pinto (2012). The Relationship between Idiosyncratic Risk and Returns in the Brazilian Stock Market, Pontifical Catholic University of Rio de Janeiro. Brazil.

Francis J. and K. Schipper (1999): Have financial statements lost their relevance? Journal of Accounting Research.

Frees,E ( 2004). Longitudinal and panel data analysis and application in the social science, Cambridge University press.

Fu, F. (2009) Idiosyncratic Risk and the Cross-Section of Expected Stock Returns. Journal of Financial Economics.

Gachucha K. (2014) An examination of the relationship between financial management Practices and stock returns of listed companies in the NSE. University of Nairobi. chss.uonbi.ac.ke/sites

Goetzman, W. N. and Kumar, A. (2008) Equity portfolio diversification, Review of Financial Studies.

Hashemijoo, M. and Ardekani, M. (2012). The Impact of Dividend Policy on Share Price Volatility in the Malaysian Stock Market, Journal of Business Studies Quarterly.

Heinkel, R. (1982) “A Theory of Capital Structure Relevance under Imperfect Information” the Journal of Finance 37 (5).

Holmes, G., Sugden, A. and Gee, P. (2008) Interpreting Company Reports, $10^{\text {th }}$ Edition, FT Prentice Hall, USA.

Hsiao, C. (2003). Panel Data Analysis - Advantages and Challenges, Vol.0. Department of Economics, University of Southern California, USA Wang Yanan Institute for Studies in Economics, Xiamen University, China.

Huang,C (2014) Analysis on Financing Difficulties for SMEs due to Asymmetric Information School of Management, Guangdong University of Technology, Guangzhou, China. Global Disclosure of Economics and Business, Volume 3, No 2.

Hussainey, K. and Mgbame, C. (2011). Dividend policy and share price volatility: UK evidence. Journal of Risk Finance.

Leary, M.R. (2001), Introduction to Behavioral Research Methods (3rd Ed.) Allyn \& Bacon, Boston, USA.

Levin, M. (1988). The opening of vision: Nihilism and the postmodern situation. London: Routledge.

Liu, J. \& Liu, C. (2007). Value relevance of accounting information in different stock market segments: The case of Chinese A-, B-, and H-shares, Journal of International Accounting research, 6 (2), pp. 55-81.

Maina J. (2009). An empirical investigation of stock returns reaction around earnings announcements for quoted companies at NSE. MBA project, University of Nairobi.

Malkiel, B. and Xu Y. (2003) Investigating the Behaviour of Idiosyncratic Volatility. Journal of Business.

Malkiel, B., Xu, Y. (2006), Idiosyncratic Risk and Security Returns, Working paper, Princeton University.

Malkiel, Burton G., and $\mathrm{Xu}, \mathrm{Y}$. (2006), idiosyncratic risk and security returns, working paper, University of Texas at Dallas.

Mandal, N. (2013) Sharpe's single index model and its application to construct optimal portfolio: an empirical study. Great Lakes Center for management research, Vol.7, No.1.

Nassar, L.M., Uwuigbe, O.R., Uwuigbe, U. and Abuwa, J.T. (2014). IFRS Adoption and Its Integration into Accounting Education Curriculum in Nigerian Universities, Research Journal of Finance and Accounting, 5 (22), pp. 76-82.

Reilly, F. and Brown, C. (2006). Investment Analysis and Portfolio Management. New Delhi: CENGAGE Learning.

Sandberg. P (2005) How Modern is Modern Portfolio Theory - A study of the approach to portfolio theory within recent real estate research.

Sarndal, C.E., Swenson, B., and Wretman, J. (1992), Model Assisted Survey Sampling, New York: SpringerVerlag Inc.

Sasa, A.M. (2013).The relationship between capital structure and stock price volatility at the NSE. MBA project, University of Nairobi.

Saunders, M., Lewis, P. \& Thornhill, A. (2009).Research methods for business students. (5th Edition). London: Prentice Hall.

Sekeran, U. (2003), Research method for business, fourth edition. Southern Illinois University

Sharma, S. (2011).Determinants of Equity Share Prices in India. Journal of Arts Science and Commerce.

Sharpe F. (1964). Capital Asset Prices, Journal of Finance, September 1964, pages 42- 442. 
Shehzad, K. and Ismail, A. (2014) Value relevance of Accounting Information and its Impact on Stock Prices: Case Study of Listed Banks at Karachi Stock Exchange. Readers Insight Publisher. Journal of Economic. $3(1), 40-48$.

Shin, J. (2005). Stock Returns and Volatility in Emerging Stock Markets. International Journal of Business and Economics, 4(1), 31-43

Sibel K, (2013) The Impact of IFRS on the Value Relevance of Accounting Information: Evidence from Turkish Firms. School of Business Administration, Celal Bayar University, Manisa, Turkey. Published by Canadian Center of Science and Education.

Siegel, G. and Jae S. (2010) Accounting Handbook. 5th ed. Hauppauge, N.Y.: Barron's Educational Series.

Spence M. (1973) "Job Market Signaling.” The Quarterly Journal of Economics 87(3) (1973) 355-374.

Spiegel, M., Wang, X. (2005), Cross-sectional variation in stock returns: liquidity and idiosyncratic risk, working paper, Yale University.

Stickel, S. (1991). Common stock returns surrounding earnings forecast revisions: more puzzling evidence. The Accounting Review.

Stock return volatility, journal of accounting research (studies on accounting information and the economics of the firm).

Tran, N. and Nguyen, T. (2015) Market Efficiency and Idiosyncratic Volatility in Vietnam. School of Finance, University of Economics Ho Chi Minh City, Vietnam. International Journal of Business and Management; Vol. 10, No. 6;

Tuli, Nishi and Mittal, R.K. (2001). Determinants of Price-Earnings Ratios. Finance India.

Waithaka, A. (2012) The relationship between working capital management practices and financial performance of agricultural companies listed at the NSE. University of Nairobi.

Wang and Chang (2008) The Association Between Accounting Information Disclosure and Stock Price, National Taipei University. Taiwan

Wang, J., Fu, G. and Luo, C. (2013). Accounting Information and Stock Price Reaction of Listed Companies; Empirical Evidence from 60 Listed Companies in Shanghai Stock Exchange, Journal of Business \& Management.

Wooldridge, J.M., (2007), Econometric Analysis of Cross Section and Panel Data (second ed.) MIT Press. 